\title{
Wear and Friction Modelling on Lifeboat Launch Systems
}

\begin{tabular}{|c|c|}
\hline Journal: & Tribology Transactions \\
\hline Manuscript ID: & UTRB-0438.R1 \\
\hline Manuscript Type: & Manuscript for Publication Only \\
\hline $\begin{array}{r}\text { Date Submitted by the } \\
\text { Author: }\end{array}$ & 24-Nov-2009 \\
\hline Complete List of Authors: & $\begin{array}{l}\text { Hadfield, Mark; Bournemouth University, School of Design, } \\
\text { Engineering and Computing } \\
\text { Thomas, Ben; Bournemouth University, School of Design, } \\
\text { ENgineering and Computing } \\
\text { Austen, Steve; Royal National Lifeboat Institution }\end{array}$ \\
\hline Keywords: & $\begin{array}{l}\text { Marine }<\text { Applied Tribology, Wear Mechanisms }<\text { Wear, Friction } \\
\text { Mechanisms }<\text { Friction, Stress Analysis }<\text { Contacts, Lifeboats }\end{array}$ \\
\hline
\end{tabular}

\section{\$ ScholarONE" \\ Manuscript Central}




\title{
Wear and Friction Modelling on Lifeboat Launch Systems
}

\author{
B. Thomas ${ }^{* a}$, M. Hadfield ${ }^{\mathrm{a}}$, S. Austen ${ }^{\mathrm{b}}$. \\ Sustainable Product Engineering Research Centre, Bournemouth University, UK \\ Royal National Lifeboat Institution, Poole, $U K^{b}$ \\ * Corresponding author. Tel. +44 1202524111 \\ E-mail Address: thomasb@bournemouth.ac.uk (B. Thomas) \\ Received --/--/-- accepted --/--/--
}

\begin{abstract}
The RNLI provides search and rescue cover along the UK and RoI coast using a variety of lifeboats and launch techniques. In locations where there is no natural harbour it is necessary to use a slipway to launch the lifeboat into the sea. Lifeboat slipway stations consist of an initial section where the boat is held on rollers followed by an inclined keelway lined with low friction composite materials, the lifeboat is released from the top of the slipway and proceeds under its own weight into the water. The lifeboat is later recovered using a winch line. It is common to manually apply grease to the composite slipway lining before each launch and recovery in order to ensure sufficiently low friction for successful operation. With the introduction of the Tamar class lifeboat it is necessary to upgrade existing boathouses and standardise slipway operational procedures to ensure consistent operation. The higher contact pressures associated with the new lifeboat have led to issues of high friction and wear on the composite slipway linings and the manual application of grease to reduce friction is to be restricted due to environmental impact and cost factors. This paper presents a multidisciplinary
\end{abstract}


approach to modelling slipway panel wear and friction using tribometer testing in conjunction with finite element analysis and slipway condition surveys to incorporate common real-world effects such as panel misalignments. Finally, it is shown that a freshwater lubrication system is effective, reducing cost and environmental impacts while maintaining good friction and wear performance.

\section{KEYWORDS: \\ Lifeboats, marine, friction mechanisms, stress analysis, wear mechanisms}

\section{OVERVIEW OF SLIPWAY LAUNCHED LIFEBOAT OPERATION}

The RNLI provides search and rescue (SAR) cover around the coast of the UK and Ireland. In areas where there is no natural harbour, and the ground is not suitable for carriage launched lifeboats the only option allowing a lifeboat to launch in all weather conditions is to use an inclined slipway. The RNLI operates 18 slipway stations in the UK and 2 in the Republic of Ireland, each station is different and each has its own historical launch techniques and slipway geometries though they all follow a common template [1]. The most common configuration is to have an upper section of steel rollers leading onto a smooth, lined, lower section with a typical gradient of 1 in 5 . The boat is launched down the slipway resting on its keel with the plane slipway section coated with grease to reduce friction. The boat is recovered by manoeuvring the keel onto the bottom of the keelway before attaching a winch cable and hauling the boat to the top of the slipway. With the advent of modern, heavier slip launched SAR (search and rescue) craft such as the $35+$ tonne Tamar class (being phased in across the country from 2005) [2, 3] significant modifications to, or replacement of existing boathouses and slipways are required due to its larger size and mass with a graphite infused 
jute fibre/phenolic resin composite material originally developed as a dry or water lubricated marine bearing as the preferred lining for all new and reconditioned slipways.

\begin{abstract}
The composite has been chosen in part for its proposed ability to achieve suitably low friction coefficients without the use of grease, which is currently manually applied to the slipway lining before each launch and recovery.
\end{abstract}

\begin{abstract}
Real-world slipway use has highlighted a number of issues with high friction and wear of composite slipway panels, particularly at the newly reconditioned slipways currently using the new Tamar lifeboat. Slipway performance is regularly assessed by the RNLI during slipway trials, here the boat is recovered to the top of the slipway using a winch fitted with a load cell, the recorded load is used to calculate the dynamic and static friction coefficients during a series of hauls. Friction performance has been observed to be unpredictable, this manifests as high winch loading as the lifeboat is recovered to the top of the slipway. This has implications for the winch lifespan and for the wider reliable operation of slipway launched lifeboats. Wear performance is also observed to be poor with composite panels noted to be eroding very quickly, often requiring replacement within months or even weeks compared to the expected panel design life of 2 years. This has implications for reliable lifeboat operation and for the maintenance costs of slipways, the composite panels are expensive and current replacement rates are shown to be financially unsustainable.
\end{abstract}

This work is intended towards a method for evaluating the friction and wear performance of the graphite infused jute fibre/phenolic resin composite slipway lining and to identify and reduce the 
causes of high friction and high wear on the slipway panels. Suitable lubricants to ensure low friction coefficients and hence reliable slipway operation are also investigated.

\title{
FIG 1
}

\section{PREVIOUS WORK}

Previous work in this area has involved using tribometer testing to evaluate the friction [4] and wear [5] performance of slipway panels. This revealed that the dry sliding friction coefficient of the composite slipway panels under normal in-service loading was not sufficient to ensure reliable slipway performance; hence, a lubricant is required.

\begin{abstract}
Lubricants tested included the currently used marine grease, two biodegradeable greases suggested for direct substitution with the marine grease, a cable pulling lubricant used at Sennen Cove slipway station and freshwater and seawater lubrication systems. All lubricants bar one of the biogreases were found to be suitable for reducing friction along the slipway to within design limits. This led to the recommendation to adopt a water lubrication system due to its low initial and operating costs, low environmental impact and good friction performance.
\end{abstract}

\begin{abstract}
Wear rates [5] were found to be uniformly low for all lubricants tested, far lower than those found on real world slipways and insufficient to explain the high failure rates and subsequent replacement costs of slipway panels. This has prompted a detailed investigation and condition survey of existing slipways for indications as to the causes of the high wear observed.
\end{abstract}




\title{
SLIPWAY CONDITION SURVEYS
}

Following the low wear rates noted during the tribometer testing detailed photographic surveys of real-world slipway panel conditions were conducted at a number of slipway stations operating both the new Tamar class lifeboat and the older Tyne class lifeboat to investigate why real-world wear rates are found to be so much higher than those indicated by the tribometer tests.

Photographic slipway surveys were conducted at Bembridge, Sennen cove, The Lizard, Selsey, Tenby and Padstow; with additional panel alignment surveys conducted on the new Tamar operating Tenby and Padstow slipways.

\section{Real World Slipway Panel Wear}

Wear on the composite slipway panels is observed from slipway surveys to fall into four main categories, termed panel end wear, gouging wear, plane abrasive wear and delamination wear.

\author{
Panel End Wear \\ This type of wear is reported by lifeboat crews as the main cause of panel failure. It is defined as \\ wear that takes place at the ends of each panel and appears to be more pronounced on the raised edge \\ of panels that are misaligned in relation to their neighbours. The actual wear can take different \\ forms, from simple abrasion to more complex cracking effects as detailed below.
}

\section{Panel End Abrasive Wear}


This is the most common form of panel end wear observed from the slipway surveys; it represents the case where abrasive wear has resulted in a relatively even and graded wear scar, as opposed to the larger scale panel cracking effects observed elsewhere.

\section{FIG 2}

Fig. 2 above shows the typical progression of an abrasive wear scar on a misaligned panel. Initially panel end stresses cause a small region of the composite to deteriorate and fail, this initial imperfection develops until it is the width of the lifeboat keel on the panel. Further slipway operation causes this wear scar to progress into the composite panel until it reaches the level of the fixing bolts, at this point the panel is considered to have failed as it is no longer sufficiently attached to the slipway superstructure.

\section{Panel End Cracking Wear}

Panel end stresses can also result in the formation of deep cracks in the phenolic resin of the composite, these can progress to form panel 'islands' where the phenolic resin has cracked but the jute fibre mesh retains the cracked section in place. The jute fibres eventually fail leaving the cracked material to break loose of the main panel, this results in distinctive large scale missing 'chunks' on the panel ends. This effect is noted to be more pronounced on misaligned panels and is suspected to be caused by the same stress concentration effects. Fig. 3 shows the progression of this process on different panels. 
A subset of the cracking to leave panel 'islands' case is where cantilever effects (where the panel is not adequately supported after the final fixing bolts) can result in cracking of the phenolic bulk materials between the fixing bolts as show below in fig. 4 . This type of wear is severe as once the cracked section separates from the main panel the holes for the fixing bolts are broken also and the panel can be considered to have failed as it is not adequately fixed to the underlying slipway structure.

FIG 3

FIG 4

\section{Gouging Wear}

Deep, parallel gouging wear scars are observed at the new Tamar equipped Padstow and Tenby slipways. These are subsequently attributed to an imperfection in the keel of the prototype Tamar class lifeboat, used for initial slipway hauling trials at both slipways.

\section{FIG 5}

This issue has since been rectified and the absence of other significant gouging wear scars on the Tamar slipways and general slipway friction performance better than that expected from ploughing friction calculations indicate that once the prototype Tamar keel was repaired no other major gouging wear was encountered here. This is supported by the other slipway inspections at Selsey and Bembridge where some light gouging wear is present, though not to the severity that would be 
expected for the large number of launches and recoveries conducted on these slipways. This supports the proposition that significant, persistent keel damage not a common occurrence on slipways and raises the possibility that the lighter gouging wear scars on Selsey and Bembridge slipways are caused by $3^{\text {rd }}$ party wear particles trapped between the contact. This is supported by the presence of diagonal and wavy gouging scars on panels, if the scars were caused solely by keel imperfections these would be expected to run along the length of the slipway lining as the lifeboat does not move laterally as it proceeds along the slipway, this is shown in fig. 6 below:

\section{FIG 6}

Overall the impact of gouging wear on the slipway is unlikely to have a significant systemic effect on slipway function, the presence of straight gouging grooves on the slipway panels is an early indicator of keel damage and this should be identified and remedied before further slipway lining damage occurs. However, the low number of gouging wear scars on other composite slipways indicates that this is likely to be an infrequent problem. The presence of wavy or diagonal wear scars on the slipway indicates the presence of $3^{\text {rd }}$ body particles between the keel and slipway lining, as these are not attached to either contact face they are likely to be removed from the slipway by the process of lifeboat launch and recovery. Similarly the low incidence of this type of gouging wear on the slipways surveyed indicates that this is likely to be an infrequent problem, however if these wear scars are noted to appear regularly on a specific slipway it may be necessary to inspect the slipway

for debris before use. Interestingly, the diagonal wear scars indicating $3^{\text {rd }}$ body wear are also present on the water lubricated Tamar slipways at Padstow and Tenby, it had been thought that a by-product 
of the use of running water along the slipway would be to remove any potential wear debris from the slipway lining surface but this does not appear to be the case.

\section{Plane Abrasive Wear}

Plane abrasive wear occurs when the slipway panel is well aligned and the contact with the keel is even and planar, in this case the contact pressures are relatively evenly distributed along the panel and the resulting wear is light and even. This typically results in the phenolic bulk of the composite material eroding to expose the underlying jute fibres.

\section{FIG 7}

The incidence of plane abrasive wear on a panel is a sign that the panel is performing well and that the keel contact is well aligned. Under these contact conditions wear will be very light, approaching the wear rates observed during the aligned contact tribometer testing.

\section{Delamination wear}

A further wear mechanism noted is the incidence of delamination, here the upper layer of the composite has separated and worn away leaving an uneven bearing surface.

\footnotetext{
This kind of wear is noted at both of the new Tamar equipped slipways at Tenby and Padstow. The progression of delamination wear is shown in fig. 8. Here the wear is shown to develop initially as small pits the depth of a composite layer, before the pits widen and join to form large areas of delamination along the slipway.
} 


\section{FIG 8}

Close up images of delamination wear on the composite slipway lining material are shown in fig. 9.

\section{FIG 9}

Delamination of the composite slipway panels implies that there are high shear stresses present in the composite bulk around the contact area, and this in turn implies that friction forces and friction coefficients are high in these regions. This leads to the conclusion that the presence of delamination on slipway panels indicates well aligned contact conditions, but high frictional forces on the panel. The presence of delamination wear on the new Tamar equipped slipways may be due to a breakdown of the lubrication regime to allow unlubricated contact or a consequence of running the slipway dry.

\section{Impact Wear}

Near the base of the slipway some lining panels were observed to have been damaged by the impact of the keel as the lifeboat mounts the slipway. The recovery technique involves the coxswain trying to 'surf' onto the base of the slipway on a wave, the water subsequently receding to leave the lifeboat sufficiently 'stuck' on the slipway to attach the winch cable. This naturally involves the keel impacting the slipway lining with some force and this can occasionally damage the slipway panels.

\section{Embedded Debris}


Embedded debris is noted at Selsey slipway, conversations with the coxswain indicate that this is likely to be animal shells, this is confirmed by observation of snails and snail trails on slipway panels.

\section{FIG 10}

\section{PANEL MISALIGNMENT SURVEYS}

Photographic surveys of a number of real world slipways were conducted in order to develop a picture of the typical wear patterns developed by the slipway panels. During these investigations it was observed that there was sometimes severe misalignment between slipway panels along the slipway. It was noted that the most severely worn panels seemed to coincide with the more pronounced panel misalignments and this led to more comprehensive slipway panel surveys at the new slipway stations of Tenby and Padstow to ascertain the extent of this misalignment.

\section{Tenby Slipway Panel Alignment Survey}

Measurements of the height difference between slipway panels were taken at each corner of each panel and recorded for the extent of both slipways above the waterline. These show that the panel misalignment is present and significant, reaching a peak of $3.52 \mathrm{~mm}$ height difference between panel 18 and 19 (panels are numbered from the top of the slipway towards the waterline). Wear on panel 19 (raised in relation to panel 18) is observed to be primarily end wear with cracking well developed on the panel despite it having been only recently replaced. Overall the slipway shows an average height difference between panels of $0.88 \mathrm{~mm}$ with a maximum of $3.52 \mathrm{~mm}$. 


\begin{abstract}
Padstow Slipway Panel Alignment Survey
At Padstow it is also observed that the composite panels with the most pronounced end wear are often vertically misaligned with respect to their neighbouring panels producing a raised edge which is likely to generate stress and wear concentrations. A detailed panel misalignment survey is conducted in a similar way as at Tenby slipway and it is found that panel misalignment is present and significant along the slipway with an average panel height difference of $0.73 \mathrm{~mm}$ and a maximum of $4.06 \mathrm{~mm}$.
\end{abstract}

\title{
Panel Alignment Observations
}

The panel misalignment surveys conducted at Tenby and Padstow indicate that significant panel misalignment is present along the slipway in both cases.

\begin{abstract}
The average offset for all panels recorded from both slipway surveys is $0.82 \mathrm{~mm}$. The compressive yield strain is recorded as $1.9 \%$ for the composite, on a $19 \mathrm{~mm}$ thick panel this would correspond to a displacement of $0.36 \mathrm{~mm}$, less than half of the average panel height difference along the slipway. This indicates that compressive deformation of the composite panels is not sufficient to accommodate the panel misalignments present at both Tenby and Padstow slipways, even at the maximum compressive deformation before failure. As the contact stresses around the raised edge of a misaligned slipway panel are likely to be high this will contribute to increased wear in the area and this is reflected by observation. The high contact forces will also have an adverse effect on friction according to the theory.
\end{abstract}

\section{FEA MODELLING OF EXISTING SLIPWAY PANEL GEOMETRY}


Following tribometer testing the friction and wear rates for the composite against steel under various lubrication regimes are determined. However, the wear scars generated bear little resemblance to the real world case and the friction is also observed to be far more stable. From investigation of the worn Tenby slipway panel it is noted that wear occurs, not evenly across the keel/panel contact area as expected from an evenly distributed load on a flat surface, and as generated by the tribometer tests, but unevenly, and particularly at the panel edge and area surrounding the fixing holes. This would imply that the evenly distributed load/flat surface assumption does not hold entirely for the length of the lifeboat keel in the real world case. Site surveys undertaken at Tenby and Padstow to determine the extents and nature of the uneven wear observed found that there was significant misalignment present between panels, the nature of which could be roughly categorised into three misalignment scenarios. It is thought that this deviation from the evenly distributed load/flat surface contact may be a cause of the higher than expected friction and wear observed on real world lifeboat slipways. In order to assess the impact of the panel geometry and alignment on the wear rate it is proposed to use finite element methods in ANSYS coupled with the friction and wear data derived experimentally from tribometer testing.

\section{FIG 11}

\section{One Panel Aligned Case}

Finite Element techniques are used to model the static case of an evenly distributed load along the lifeboat keel on a composite slipway panel; results are shown below for the Von Mises stresses on the panel. 
It is found that the areas of high stress concentrations correlate well with the worn regions observed on composite panels during slipway surveys and on the damaged slipway panel recovered from Tenby slipway station as shown in fig 12.

The stress concentrations on the FEA model are seen to occur around areas close to geometric features, particularly the panel edge and fixing hole areas. This would indicate that geometric considerations are an important factor in determining the likely local wear rate and friction on a slipway panel due to the stresses concentrated in these areas.

\section{FIG 12}

\section{Wear Simulation}

Using element death techniques and appropriate element failure criteria a wear scar can be developed within the FEA model. This is done by using a fine element mesh around the expected wear concentrations, elements exhibiting stresses above the material failure criteria are 'killed' and removed from the analysis, generating a wear scar. Using iterative techniques this wear scar can be modelled over time to show the likely progression of wear on the slipway panel. The wear scar generated is shown to correlate well with the real world case as shown below.

\section{FIG 13}

Using this technique the wear progression on the composite slipway panel can be modelled beyond the current subjective visual replacement criteria as shown below. This data indicates that the initial 
edge wear will develop over time into more serious progressive wear, a feature also observed during slipway surveys where panels exhibiting different stages of edge wear indicated the same progression. The wear modelling below also shows the development of delamination, predicting that this type of wear will be more pronounced around geometric features such as panel fixing holes, this again confirms observations from real world slipway panel surveys.

\begin{abstract}
Another aspect of this simulation of wear progression is that the panel bearing area is progressively reduced as the composite material is abraded with a consequential increase in the apparent contact pressure as the lifeboat mass load is distributed over a reduced area. This will lead to an increase in both the wear rate, which is show from rotary tribometer testing [5] to be directly proportional to the applied load, and also in the friction force, which is shown by reciprocating tribometer testing to be proportional to the applied load [4].
\end{abstract}

\title{
FIG 14
}

\section{Wear and Friction Map Generation}

Wear and friction maps are generated from the FE solution data to indicate the likely wear and friction across the surface area of the present panel design. The friction map is generated directly from the FE solution data which incorporates the friction coefficient of 0.25 recorded during dry sliding tribometer tests. Similarly, the wear map incorporates the wear coefficient data from rotary tribometer testing to produce a realistic wear expectation under the various lubrication regimes tested. Presented here is the dry sliding case, wear and friction patterns are similar for lubricated cases. 


\section{FIG 15}

Fig. 16 again shows a good correlation between the wear predicted by the FEA model and real world wear. This result indicates that the most severe panel wear is concentrated at the panel ends, followed by wear around the panel fixing holes and along the keel contact track, a result also seen on composite panels from slipway surveys.

This wear map represents the aligned contact case and mirrors the slipway survey observations of light panel end wear and delamination wear on slipway panels that were noted to be reasonably well aligned (less that $1 \mathrm{~mm}$ height difference) with respect to neighbouring panels.

\section{FIG 16}

\section{Two Panel Aligned Case}

The one panel case is expanded to a two panel case to examine the stresses at the panel/panel interface. It is found that the two panel case closely mirrors the 1 panel case when the panels are modelled as being perfectly aligned to each another, with the wear on each panel similarly mirrored. It is now possible to expand this case to include some of the panel misalignment effects encountered on real world slipways.

\section{FIG 17}




\section{TWO PANEL MISALIGNMENT MODELLING}

From slipway site panel surveys it is seen that the height difference between panels can be up to $4 \mathrm{~mm}$, this may be an important influence on the wear and friction rates of slipway panels and so a number of simulations are run to model these misalignments between 0 and $5 \mathrm{~mm}$ in height.

Three misalignment scenarios are modelled, one in which the slipway panels are assumed to have a parallel offset, both remaining in the same plane, and one where an angled offset is used, with the second panel angled in such a way as to give a panel height difference of 0 to $5 \mathrm{~mm}$ at the panel interface. Site surveys indicate that both of these scenarios are present between slipway panels with the parallel panel offset scenario predominating, making up a total of $67 \%$ of the slipway panel interfaces surveyed. The remaining $33 \%$ of panels fit the angled offset scenario. A third scenario in which the second panel is skewed longitudinally with respect to the first is also modelled, survey data indicates that this scenario is present in $22 \%$ of cases, roughly equally occurring within both the parallel and the angled offset scenarios.

Small offsets of 0-1mm are modelled for the parallel case to further investigate the effects of panel misalignment, initial screening simulations indicate that results for both parallel and angled misalignment scenarios are similar for these small offset distances. In order to reduce analysis computation times the panel models are simplified by removing the fixing holes, the stresses around these features have already been modelled in the previous 1 and 2 panel analyses where it is shown that wear at these features, although still significant, is far less than at the panel interfaces and that the related contact stresses which contribute to friction forces are also far lower. 


\section{Parallel Panel Misalignment}

The parallel panel misalignment scenario assumes that the two panels are offset while remaining parallel by between 0 to $5 \mathrm{~mm}$ as shown in the diagram below:

\section{FIG 18}

This model accounts for two thirds of the panels surveyed, with the average offset for all panels being $0.82 \mathrm{~mm}$ and the maximum being $4.06 \mathrm{~mm}$. Panel offsets of $0-1 \mathrm{~mm}$ are also modelled for this scenario to further clarify the panel interface behaviour for these small offset distances.

\section{Angled Panel Misalignment}

The parallel panel misalignment scenario assumes that the two panels are offset by between 0 and $5 \mathrm{~mm}$ at the panel interface due to one panel lying at an angle to the slipway bed as shown below:

\section{FIG 19}

Site surveys indicate that this model accounts for around one third of slipway panels surveyed, with the average offset angle for all panels being $0.04^{\circ}$ and the maximum being $0.18^{\circ}$. These correspond to panel interface offset heights of $0.80 \mathrm{~mm}$ and $3.92 \mathrm{~mm}$ respectively.

\section{Skewed Panel Misalignment}

The skewed panel misalignment assumes that the two panels are twisted longitudinally in relation to each other as shown in the diagram below: 
FIG 20

Site survey data indicates that this type of misalignment is present in $22 \%$ of panels, roughly equally occurring within both the parallel and angled offset scenario. Across all panels the average skewed offset angle is $0.11^{\circ}$, this corresponds to an offset height of $0.73 \mathrm{~mm}$. A maximum offset angle of $0.63^{\circ}$ was also recorded; this corresponds to an offset height of $4.32 \mathrm{~mm}$. FE simulations are conducted using an offset height of $0-5 \mathrm{~mm}$ as indicated by site survey data.

\section{Results}

Models are generated and simulations are completed for the three offset scenarios using simplified panel models for equivalent panel interface offsets of 0-5mm. The Von Mises maximum shear stress $\mathrm{S}_{\max }$ is recorded as an indicator of the general load on the panels, as is the maximum deflection $\mathrm{D}_{\max }$. Results are presented for the parallel misalignment scenario below:

\section{FIG 21}

\section{EXPECTED PANEL LIFESPAN FOR VARYING CONDITIONS}

It is now possible to develop wear predictions and failure criteria based on the wear coefficients generated by the tribometer tests and on the stress concentrations from the FEA and slipway survey data. 
The experimental tests, FEA simulations and slipway surveys conducted show that while the sliding wear coefficient between the lifeboat keel and the jute/phenolic composite is low enough to cause little concern under ideal sliding conditions, in the real world the stress concentration effects of even slight panel misalignments can result in a serious increase in slipway panel wear. Slipway surveys show that the average panel parallel offset was $0.88 \mathrm{~mm}$; with a maximum of over $4 \mathrm{~mm}$. FEA Analysis of the stress concentrations presented by this misalignment from the plane sliding case reveal that edge stresses resulting from this misalignment can increase up to 25 times that encountered in the perfectly aligned case. The contact pressure tests conducted above indicate a linear relationship between contact pressure and wear and so it would be reasonable to conclude that this would also result in a corresponding 25-fold increase in the wear rate at these high stress regions. If we then use the wear rates found from the tribometer tests and the maximum stress concentrations found from the FE Analysis for each misalignment case, the number of launches that will generate a wear scar depth of $19 \mathrm{~mm}$, the entire depth of the composite slipway panel can be calculated for these high stress regions.

\section{TABLE 1}

It is found that for the seawater lubricated case a wear scar depth equal to the $19 \mathrm{~mm}$ panel thickness will occur after just 19 launches and recoveries. This would support the experience at Tenby where initial slipway hauling trials resulted in 10 launches and recoveries during the trial; this may well have contributed to the subsequent wear failure of slipway panels.

\section{OBSERVATIONS}


The tests and slipway surveys conducted above show that while the sliding wear coefficient between the lifeboat keel and the jute/phenolic composite is low enough to cause little cause for concern under ideal sliding conditions, in the real world even slight panel misalignments can result in a serious increase in slipway panel wear. This increase in wear due to panel misalignment would be sufficient to explain the high wear observed at Tenby and Padstow with the introduction of the new Tamar class lifeboat, particularly when the initial extended slipway line trials involving ten or more ascents/descents of the slipway under winch loading are considered. While these would have had little contribution to the wear under ideal conditions, panel misalignment effects show that they constitute over $50 \%$ of the number of launches required for the most seriously misaligned panels to fail.

As can be seen in the table above, the lubricant selection can have a significant impact on the wear rates for a misaligned panel. It should be noted however that previous reciprocating tribometer [4] testing indicates that for the consistently low friction required for successful lifeboat launch and recovery it is necessary to use some form of lubrication. It is also shown in the FE analysis that the increased edge stresses associated with panel misalignment will also result in increased friction at these points, further emphasising the need for lubrication to reduce friction. For this reason it is more sensible to examine and reduce the causes of slipway panel misalignment than to select a lubricant based on the high wear rates encountered with misaligned panels.

\section{DISCUSSION}

From the simulations it can be seen that there is a significant increase in the maximum Von Mises stresses, Friction forces and wear rate encountered as the height difference between panels increases. 
This effect can be very significant, rising to 27 times the original stress and wear rates, and up to 78 times the original friction force for the perfectly aligned case compared with a $5 \mathrm{~mm}$ angled offset and the $5 \mathrm{~mm}$ parallel offset scenarios respectively. Maximum offsets of around $4 \mathrm{~mm}$ have been observed on real world slipways for both parallel and angled scenarios, these would correspond to wear rates of 25 times the perfectly aligned case and friction forces of 62 times for the angled and parallel cases respectively. Even at an offset of $1 \mathrm{~mm}$, close to the mean offset observed for all slipway panels the stresses rise to over 11 times, wear rates to 12 times and friction rises to 18 times the perfectly aligned case. These results are extremely significant and could account for a good deal of the high wear and friction experienced during lifeboat recovery in the real world. The data from the skewed scenario also shows a significant effect with stresses at the panel interface reaching almost 28 times the perfectly aligned case.

\section{Apparent Friction Coefficient Contribution}

The contribution of panel misalignments to the apparent friction coefficient are shown in table 2 below for all offset scenarios tested.

These friction coefficients represent the apparent friction that would be indicated by winch loads calculated under the assumption of the lifeboat mass being evenly supported by the slipway panels. These do not represent an increase in the actual friction coefficient of the contact, but rather a consequence of the misrepresentation of the contact case as an evenly distributed load.

The results in table 1 indicate that panel misalignment is likely to have a significant adverse effect on local friction coefficients; with apparent friction exceeding unity at a panel offset distance of $2 \mathrm{~mm}$ 
for the parallel alignment case and of $5 \mathrm{~mm}$ for the skewed and angled misalignment scenarios. This may explain the stick-slip behaviour noted to occur during winch trials at Tenby and Padstow. These simulations thus confirm the hypothesis that panel misalignment on real world slipways could be a major factor in understanding the discrepancies between real and theoretical friction and wear rates on lifeboat slipways. Survey data also confirms that such panel misalignments are present to the extent that they may contribute significantly to the wear and friction observed along the whole slipway. Panel misalignments are common to all slipways surveyed an are likely a result of the fitting techniques involved, however, for large outdoor structures such as slipways it may well be impractical to reduce alignment tolerances to wholly eliminate misalignment effects.

\section{TABLE 2}

\section{CONCLUSIONS}

These results show that panel misalignments are a significant contributor to the friction and wear of slipway panels even at very small misalignments. This presents two major options to reduce this effect, firstly the misalignments could be eliminated by setting strict panel fitting alignment tolerances and secondly the design of the slipway panels could be modified in some way to reduce the effects of panel misalignments on panel friction and wear.

\footnotetext{
Because of the difficulties likely to be involved in reducing real world systemic panel fitting tolerances to below the $\sim 1 \mathrm{~mm}$ required for reliable slipway operation it is suggested that techniques to reduce the effects of panel misalignments be investigated and this is to be the focus of future work in this area.
} 


\section{REFERENCES}

1. Warner, O: 'The lifeboat service: a history of the Royal National Lifeboat Institution, 18241974’ London : Cassell, (1974)

2. Hudson, F, D: 'The design and development of modern SAR craft - A personal view' The Royal Institution of Naval Architects, Drydocks, Launching, and Shiplift Conference, pp79-82. (2003)

3. Leach, N: ‘A Century of RNLI Motor Lifeboats’ Landmark Publishing Ltd. (2007)

4. Thomas, B, Hadfield, M, Austen, S: 'Experimental Wear Modelling of Lifeboat Slipway

Launches' Tribology International, Vol. 42, Issues 11-12, p1706-14 (2009)

5. Thomas, B, Hadfield, M, Austen, S: 'Wear Observations Applied to Lifeboat Slipway Launches' WEAR, Vol. 267, Issue 11, p2062-9 (2009) 


\section{TABLE AND FIGURE CAPTIONS:}

Fig. 1: Typical slipway launch: Tyne class lifeboat at Selsey moves down the plain sliding section of the slipway under its own weight

Fig. 2: Abrasive panel end wear: typical wear progression (left to right)

Fig. 3: Cracking panel end wear: wear scar progression: Initially high contact stresses due to panel misalignment cause a surface crack to develop in the phenolic resin bulk of the composite, this then develops until it reaches the other side of the slipway panel, at this point the cracked area is held in place solely by the jute fibre matrix. The jute fibres subsequently fail, allowing a large section of slipway panel to break free

Fig. 4: Panel end wear: cracking between fixing bolts

Fig. 5: Gouging wear from Tamar prototype

Fig. 6: 3rd body gouging wear

Fig. 7: Plane abrasive wear: exposed jute fibres

Fig. 8: Delamination wear: wear scar progression

Fig. 9: Delamination wear: detail 
Fig. 10: Embedded Debris

Fig 11: Plan view of Von Mises Stresses on slipway panel from FEA simulation

Fig. 12: FEA simulation vs. typical worn composite panel section from Tenby slipway

Fig 13: Wear Scar developed using FE iterative element death techniques compared with real world example

Fig 14: simulation of wear progression over time on a slipway panel using FE iterative element death techniques

Fig 15: Friction map from FE simulation of 1 panel under normal keel loading: Friction force is shown in Newtons and is based on a friction coefficient of 0.25 from tribometer dry sliding tests

Fig. 16: Wear Depth/m sliding map from FE simulation of 1 panel under normal keel loading: Wear Depth is based on a wear coefficient of 3.7e-5 derived from rotary tribometer dry sliding tests. A worn panel from Tenby is shown for comparison

Fig. 17: Symmetrical Wear Scar developing on a perfectly aligned two panel model 
Fig. 18: Parallel Panel Misalignment Model

Fig. 19: Angled Panel Misalignment Model

Fig. 20: Skewed Panel Misalignment Model

Fig. 21: Parallel Panel Offset Comparison

Table 1: Equivalent number of lifeboat launches/recoveries required to generate a $19 \mathrm{~mm}$ wear scar on a 4mm parallel offset misaligned slipway panel by lubricant used

Table 2: Apparent friction coefficient contributions for modelled offset scenarios 


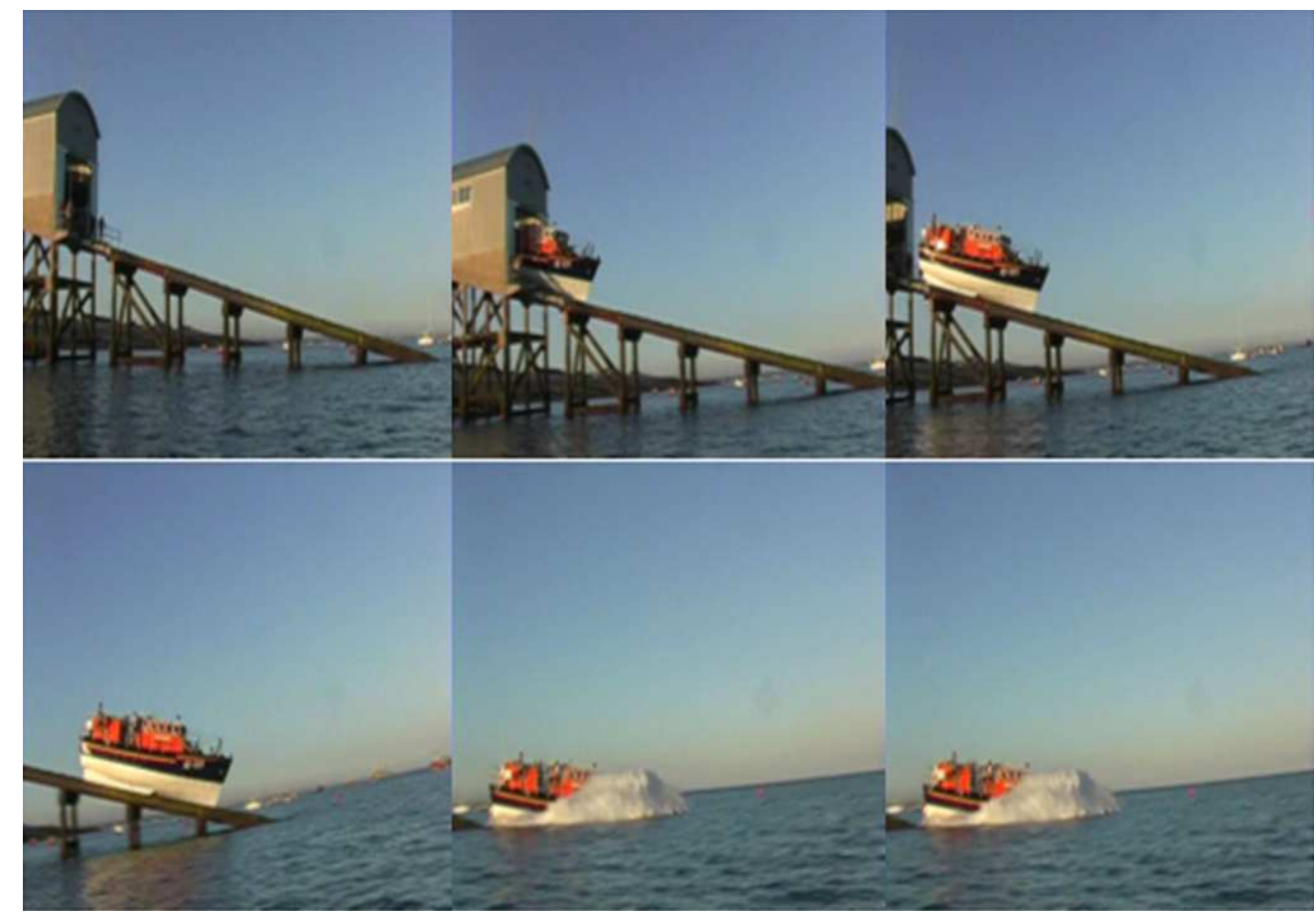

Fig. 1: Typical slipway launch: Tyne class lifeboat at Selsey moves down the plain sliding section of the slipway under its own weight $225 \times 120 \mathrm{~mm}$ (115 x $150 \mathrm{DPI})$ 

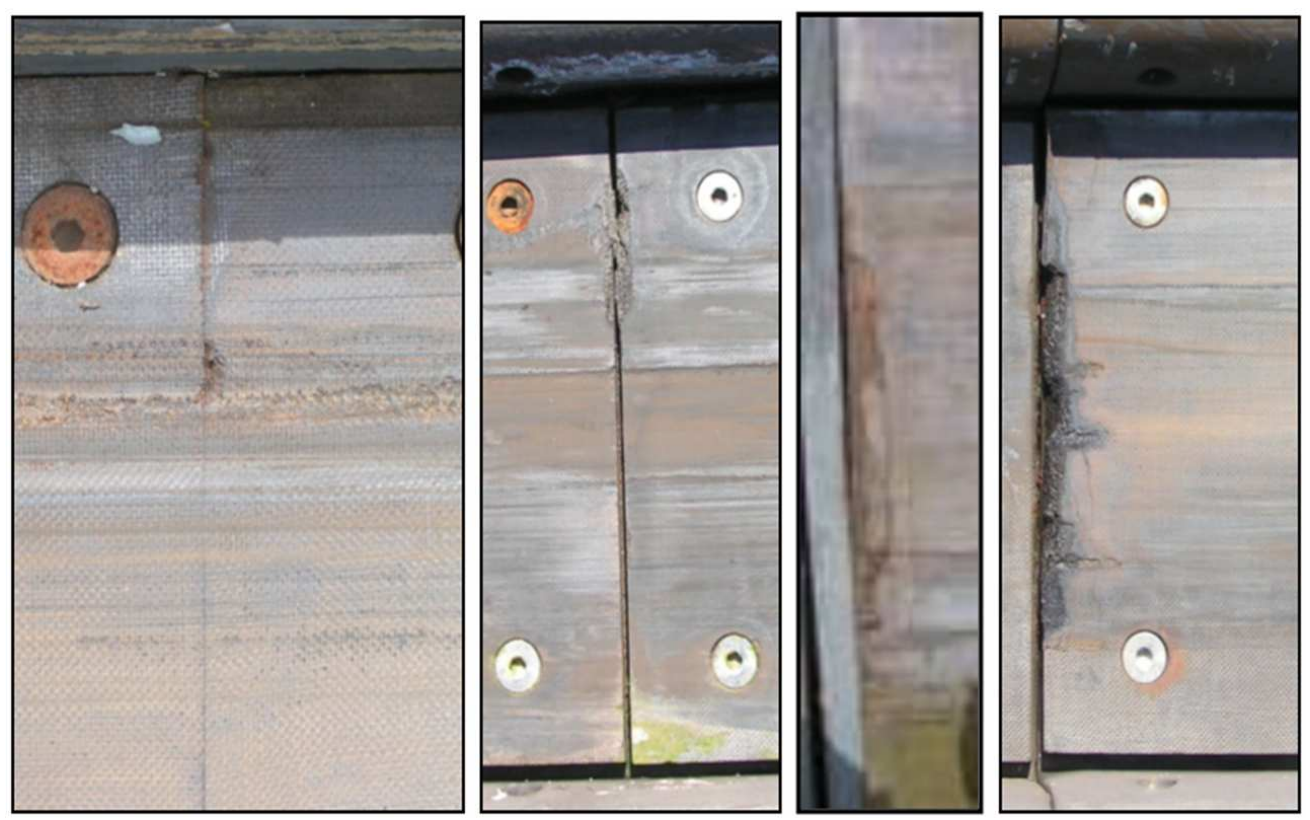

Fig. 2: Abrasive panel end wear: typical wear progression (left to right) $247 \times 135 \mathrm{~mm}(132 \times 150 \mathrm{DPI})$ 
Fig. 3: Cracking panel end wear: wear scar progression: Initially high contact stresses due to panel misalignment cause a surface crack to develop in the phenolic resin bulk of the composite, this then develops until it reaches the other side of the slipway panel, at this point the cracked area is held in place solely by the jute fibre matrix. The jute fibres subsequently fail, allowing a large section of slipway panel to break free $96 \times 268 \mathrm{~mm}(150 \times 150 \mathrm{DPI})$

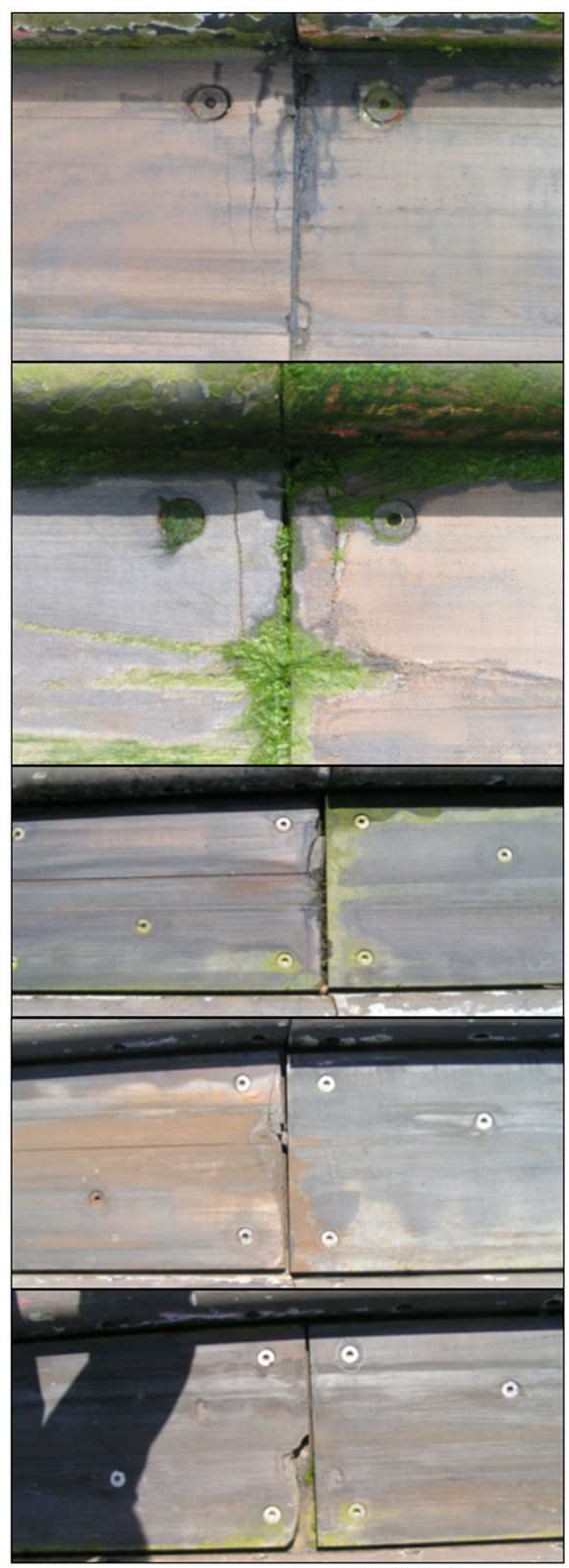




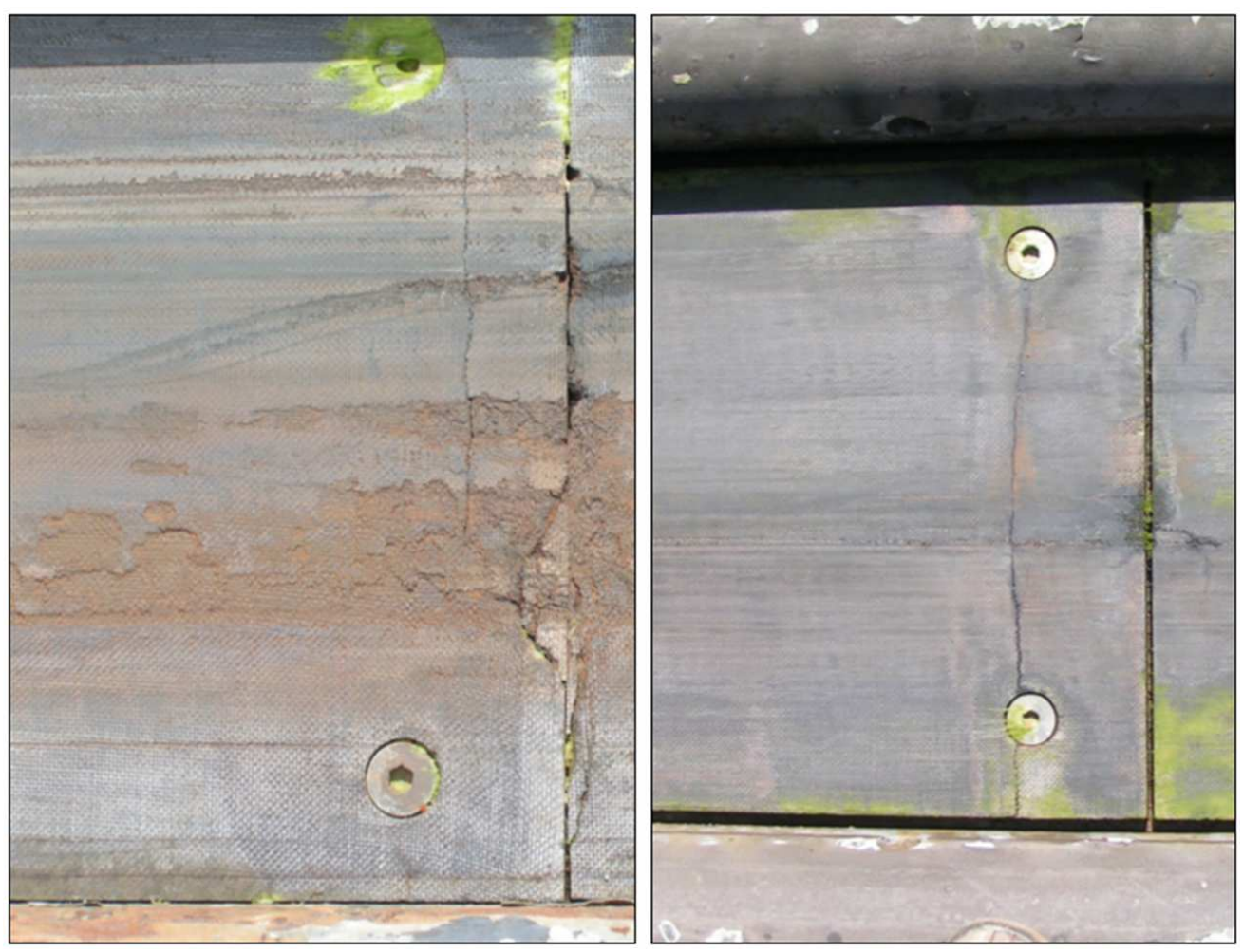

Fig. 4: Panel end wear: cracking between fixing bolts $227 \times 165 \mathrm{~mm}(143 \times 150 \mathrm{DPI})$ 


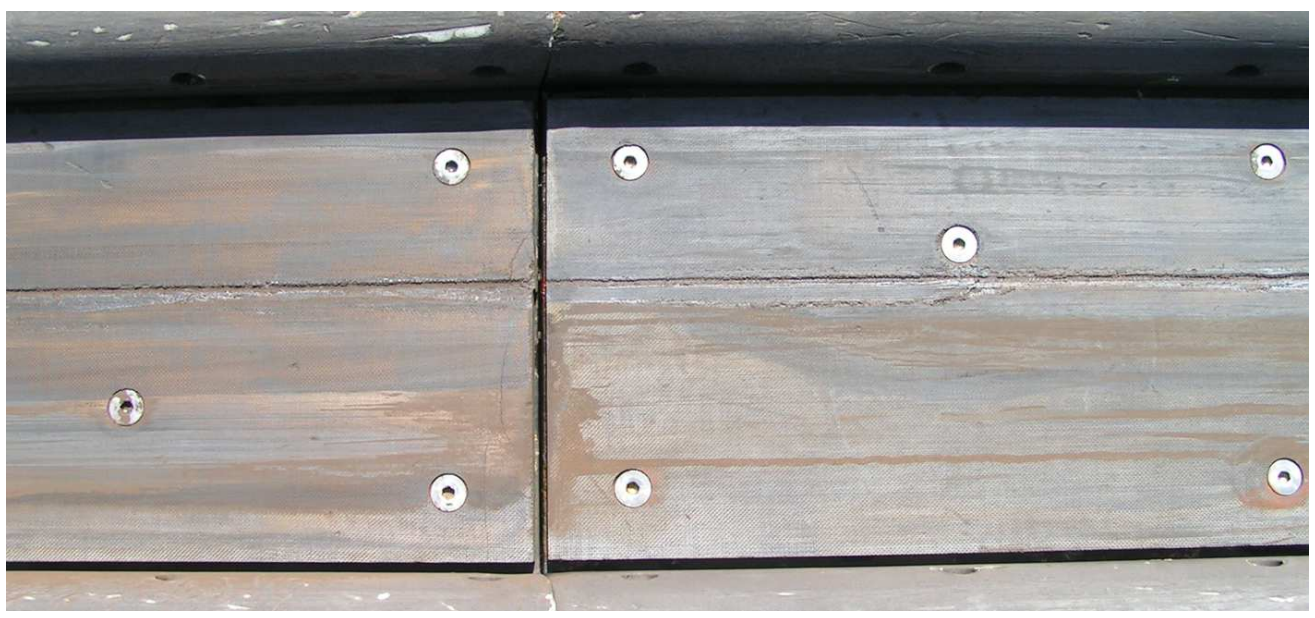

Fig. 5: Gouging wear from Tamar prototype $238 \times 109 \mathrm{~mm}(150 \times 150 \mathrm{DPI})$ 


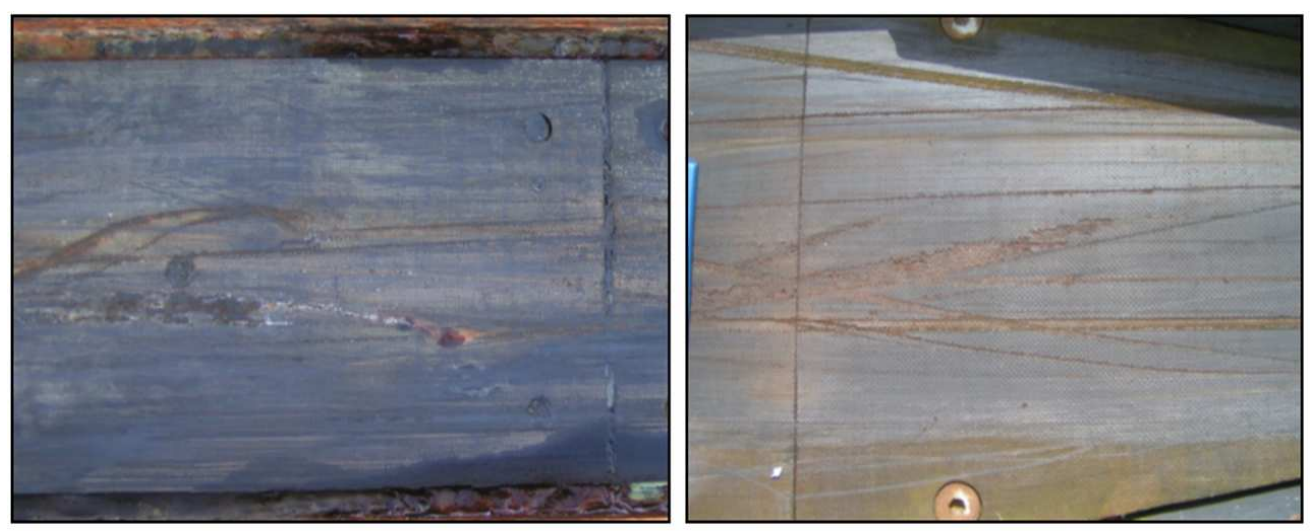

Fig. 6: 3rd body gouging wear $239 \times 87 \mathrm{~mm}(136 \times 150 \mathrm{DPI})$ 

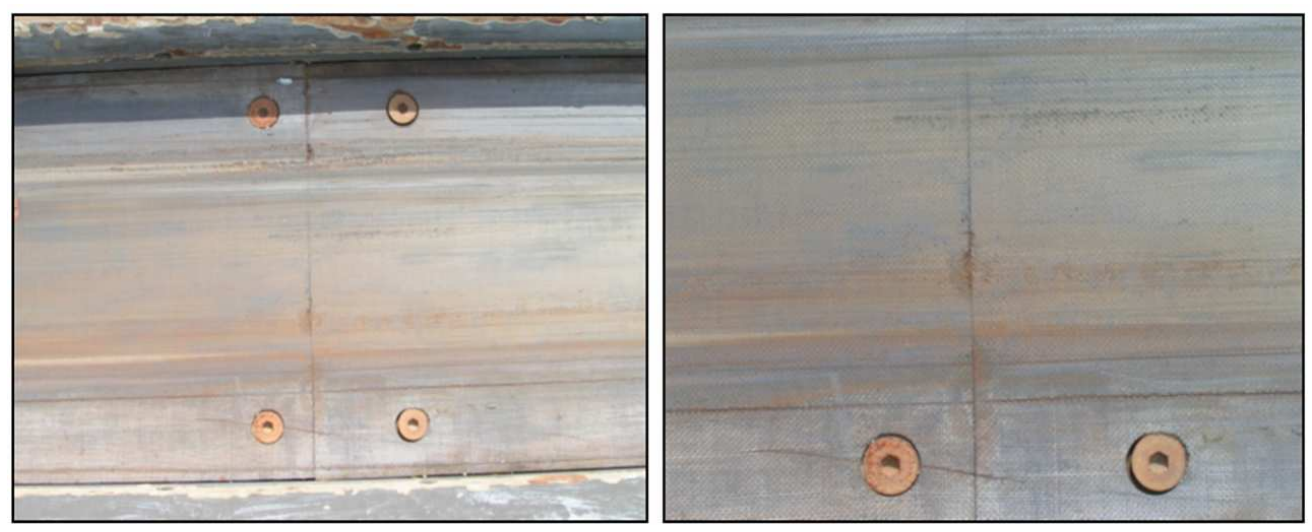

Fig. 7: Plane abrasive wear: exposed jute fibres $230 \times 86 \mathrm{~mm}(141 \times 150 \mathrm{DPI})$ 


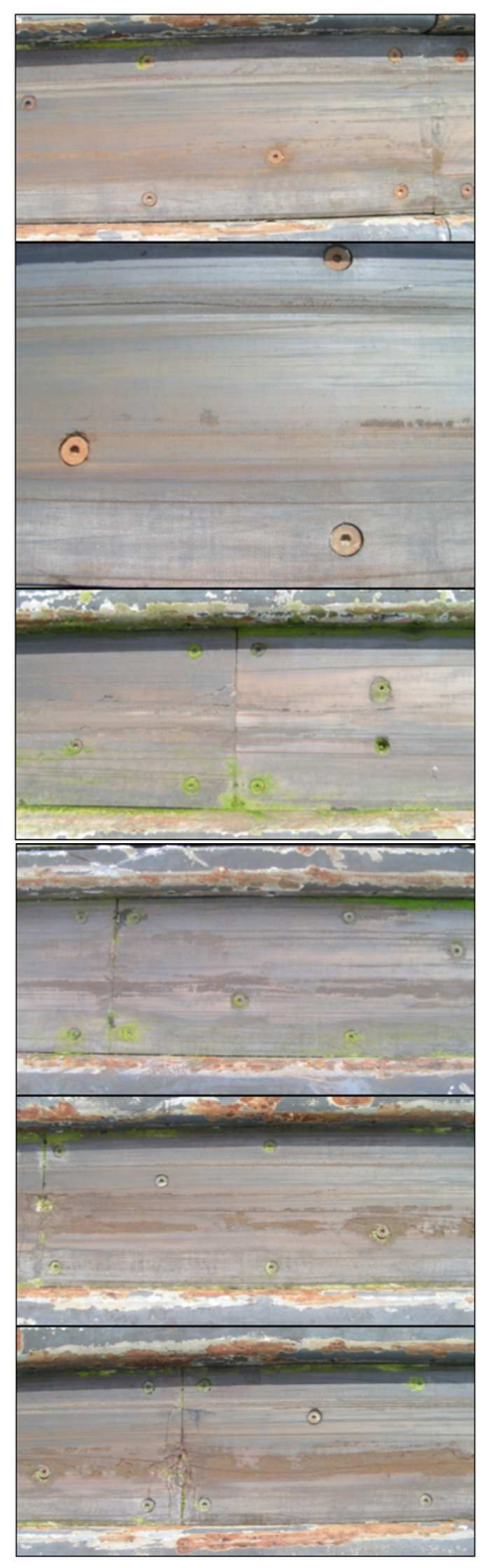

Fig. 8: Delamination wear: wear scar progression $112 \times 375 \mathrm{~mm}(150 \times 150 \mathrm{DPI})$ 


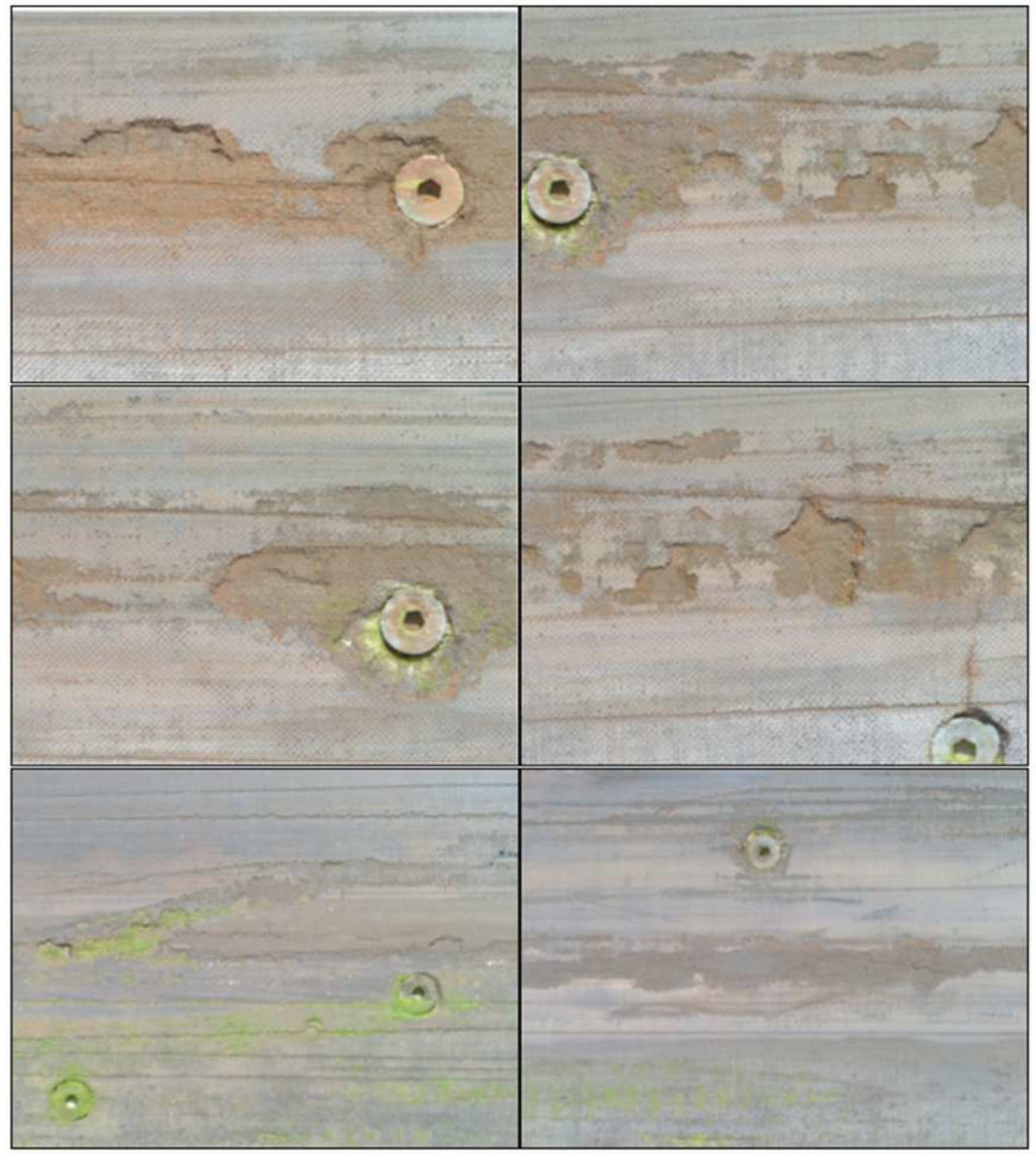

Fig. 9: Delamination wear: detail $149 \times 167 \mathrm{~mm}(150 \times 150 \mathrm{DPI})$ 

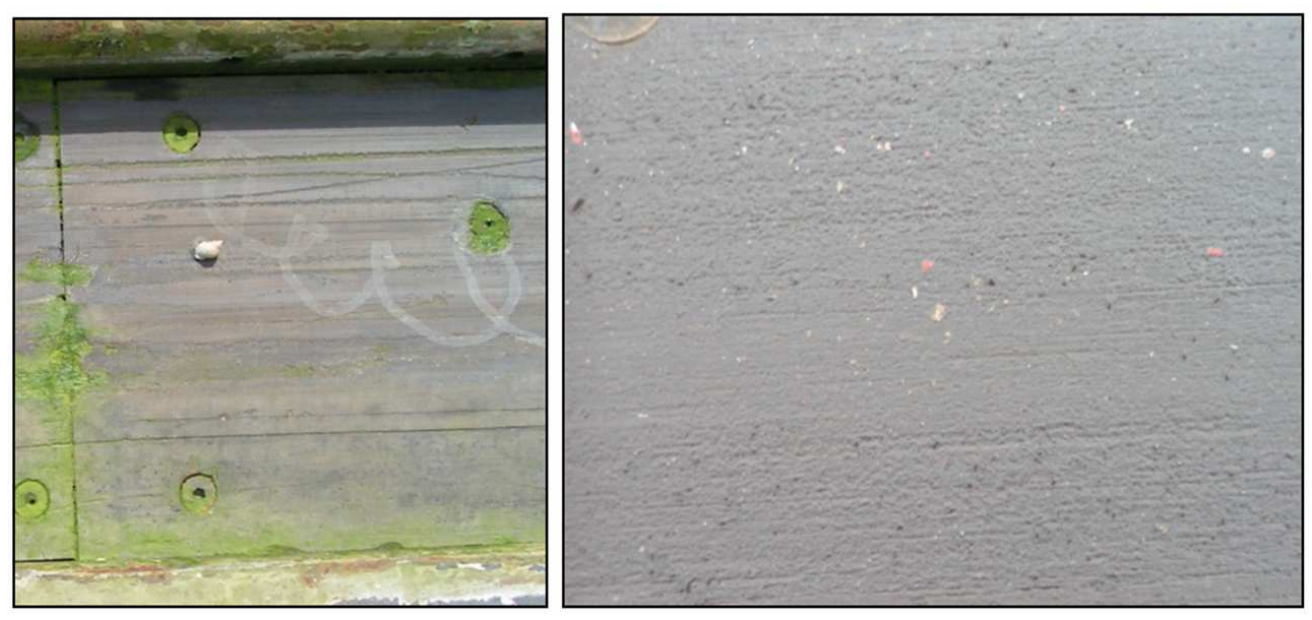

Fig. 10: Embedded Debris $230 \times 102 \mathrm{~mm}(141 \times 150 \mathrm{DPI})$

3

4

5

6
7

8

9

10

11

12

14

15

16

17

18

19

21

22

23

24

25

26

27

28

29

30

31

32

33

34

35

36

37

38

39

40

41

42

43

44

45

46

47

48

49

50

51

52

53

54

55

56

57

58

59

60

http://mc.manuscriptcentral.com/tandf/tribtrans, E-mail: ajackson@stle.org 


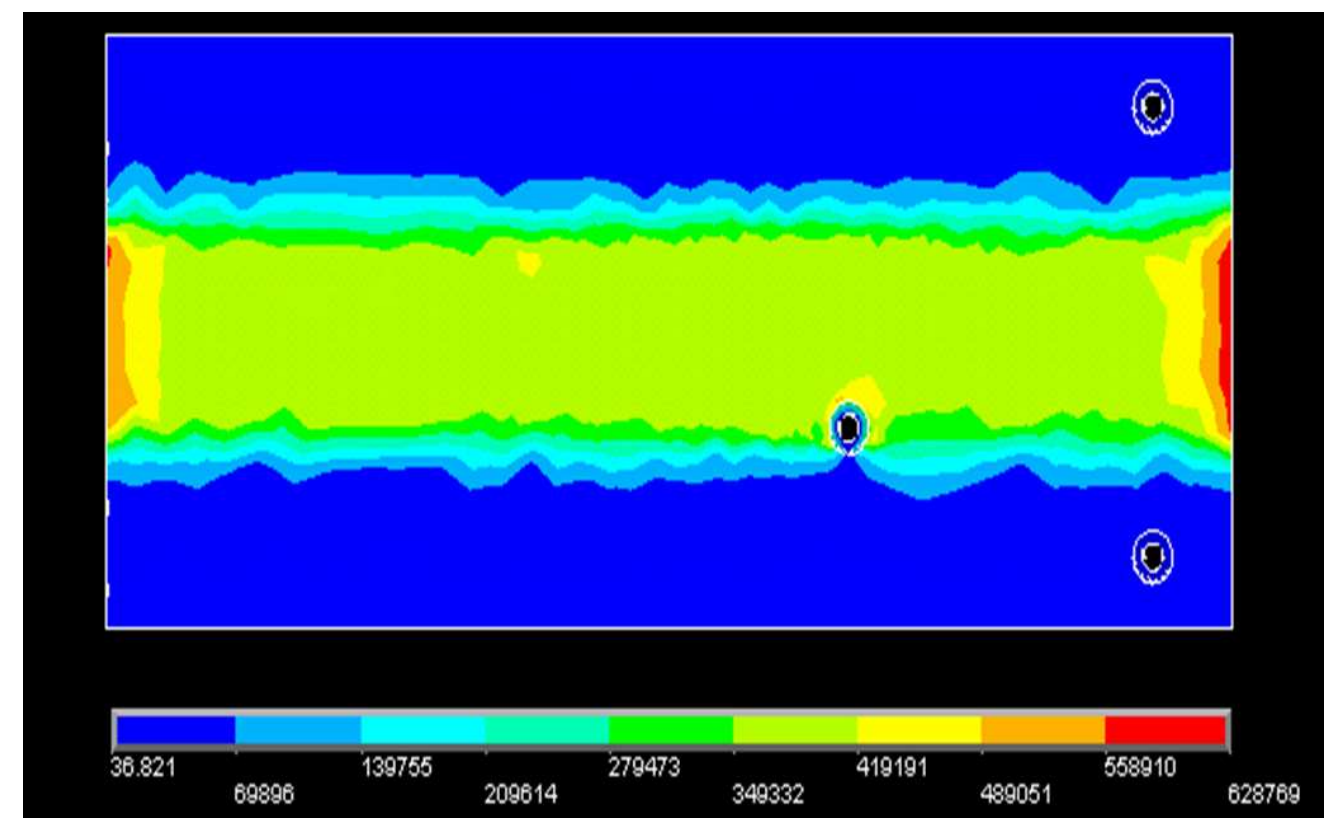

Fig 11: Plan view of Von Mises Stresses on slipway panel from FEA simulation $236 \times 107 \mathrm{~mm}(110 \times 150 \mathrm{DPI})$ 

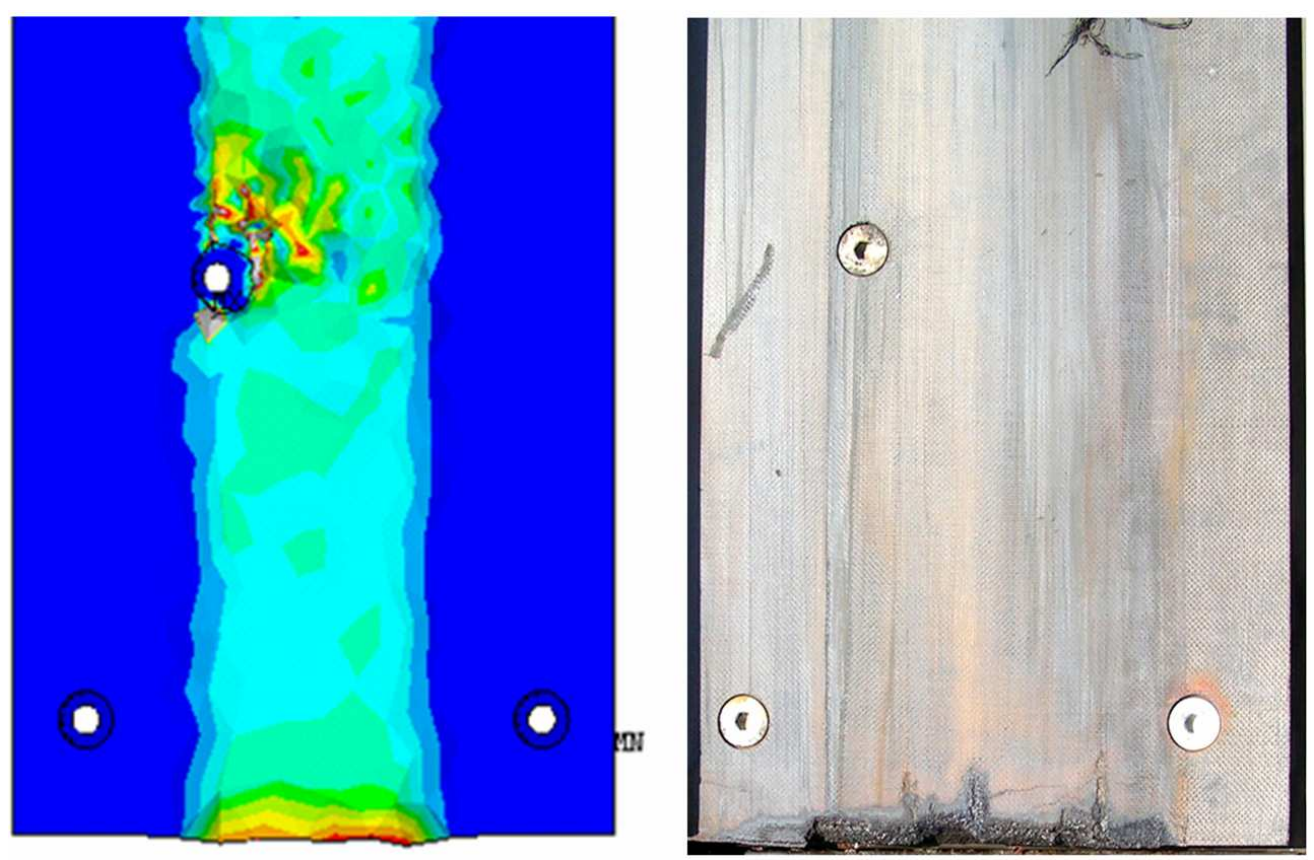

Fig. 12: FEA simulation vs. typical worn composite panel section from Tenby slipway $245 \times 141 \mathrm{~mm}(133 \times 150$ DPI $)$ 
Fig 13: Wear Scar developed using FE iterative element death techniques compared with real world example $219 \times 129 \mathrm{~mm}(29 \times 29 \mathrm{DPI})$ 

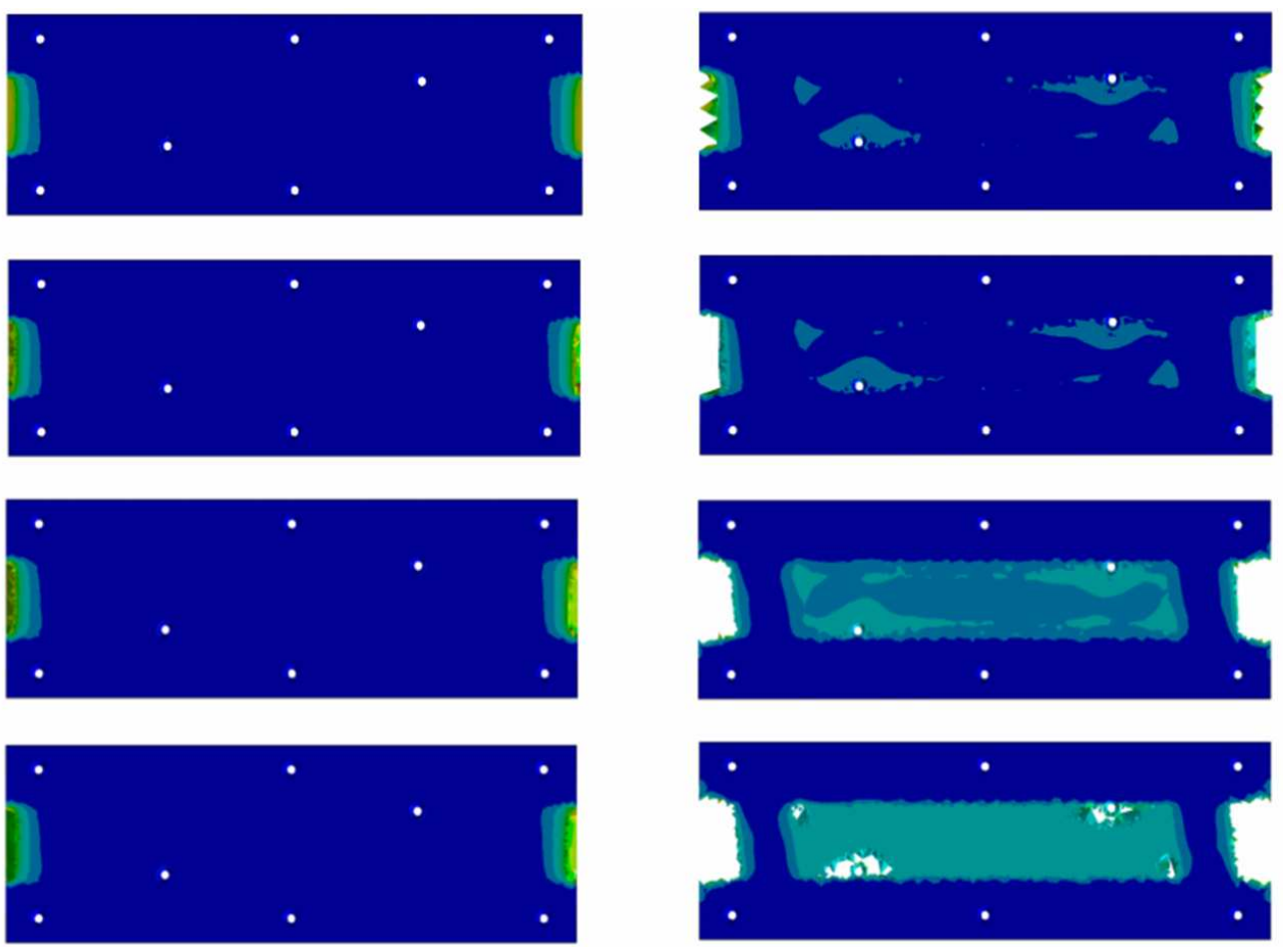

Fig 14: simulation of wear progression over time on a slipway panel using FE iterative element death techniques $235 \times 155 \mathrm{~mm}(138 \times 150 \mathrm{DPI})$ 


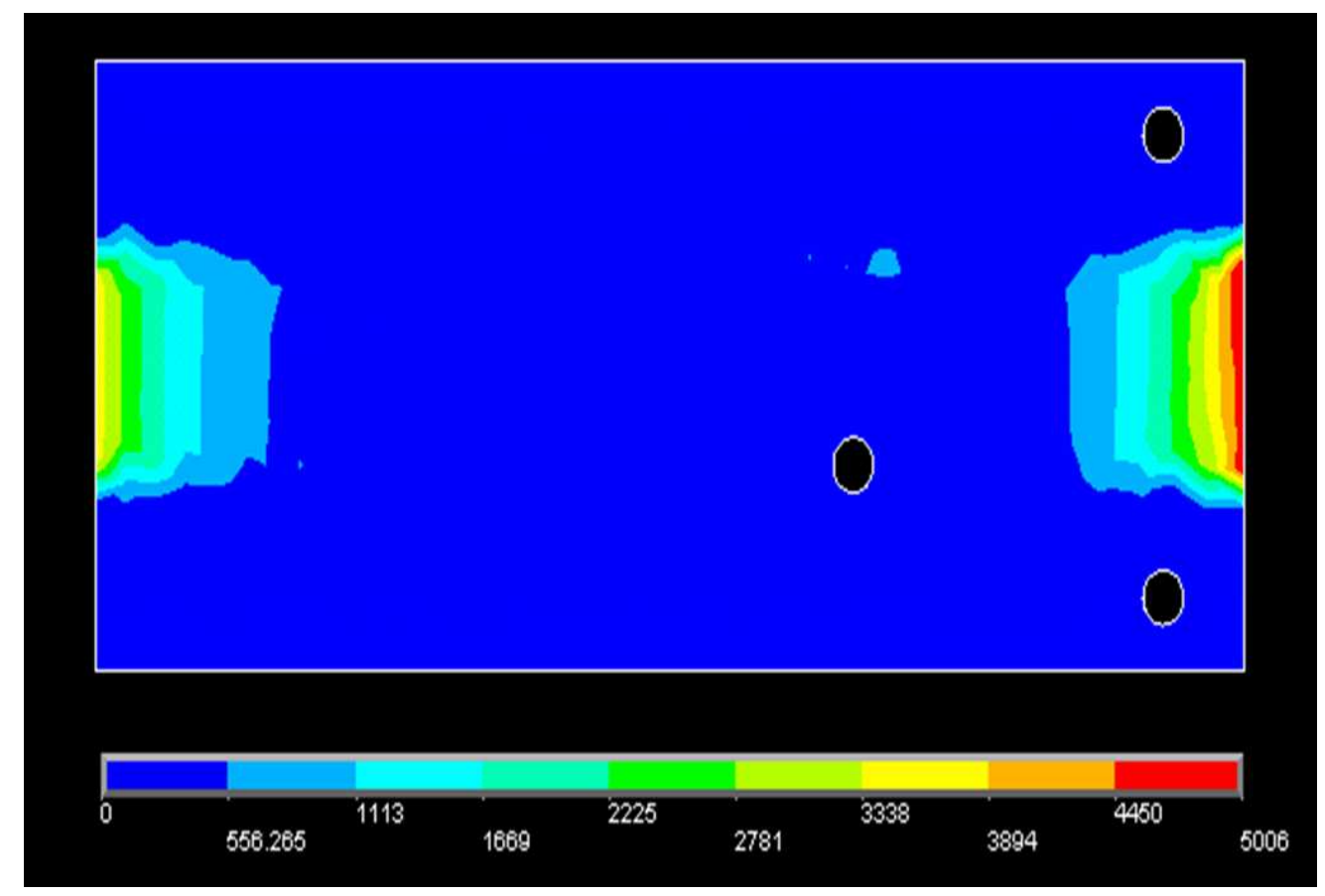

Fig 15: Friction map from FE simulation of 1 panel under normal keel loading: Friction force is shown in Newtons and is based on a friction coefficient of 0.25 from tribometer dry sliding tests $235 \times 117 \mathrm{~mm}(111 \times 150 \mathrm{DPI})$ 


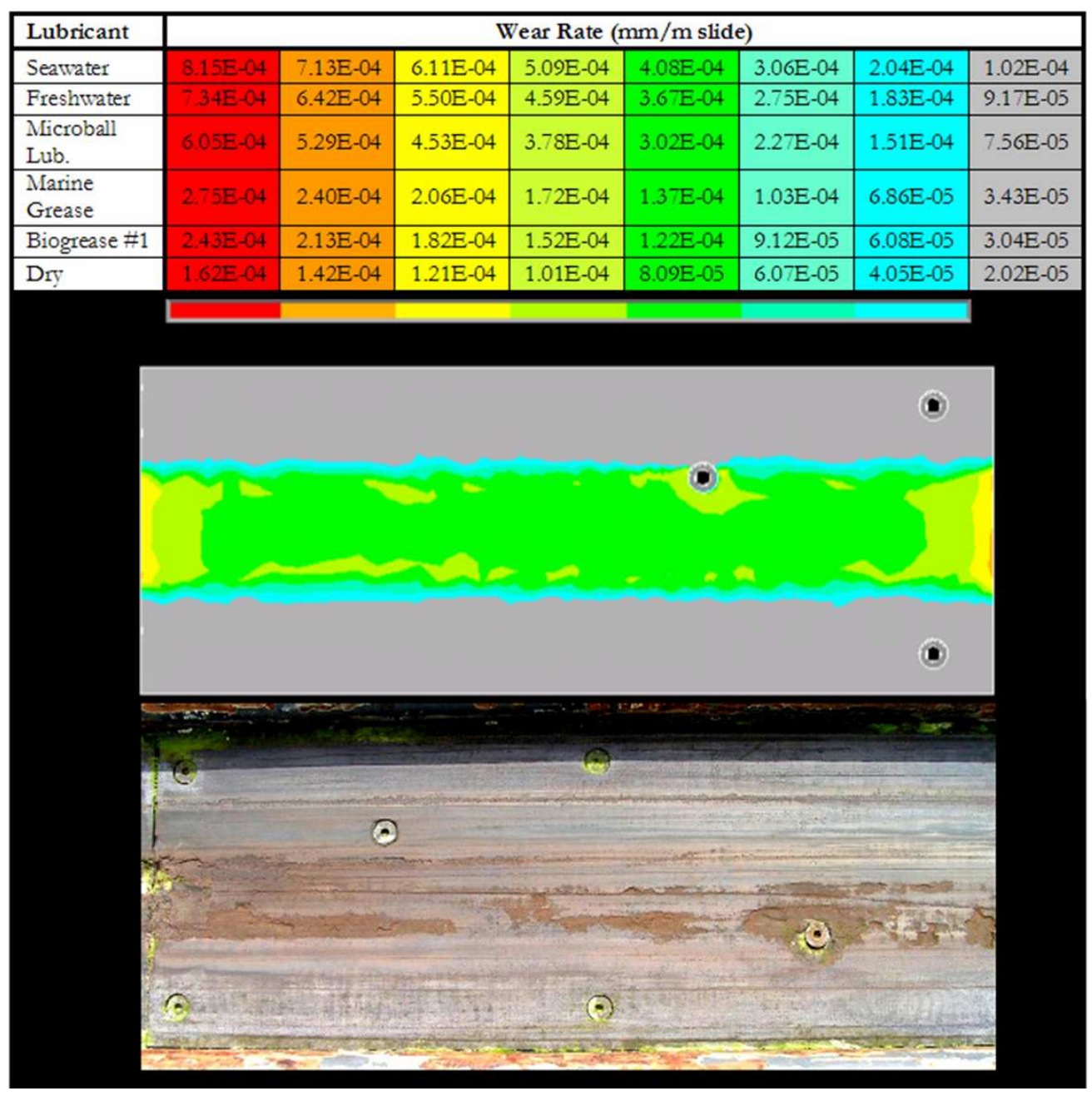

Fig. 16: Wear Depth/m sliding map from FE simulation of 1 panel under normal keel loading: Wear Depth is based on a wear coefficient of 3.7e-5 derived from rotary tribometer dry sliding tests. A worn panel from Tenby is shown for comparison $197 \times 196 \mathrm{~mm}(150 \times 150 \mathrm{DPI})$ 

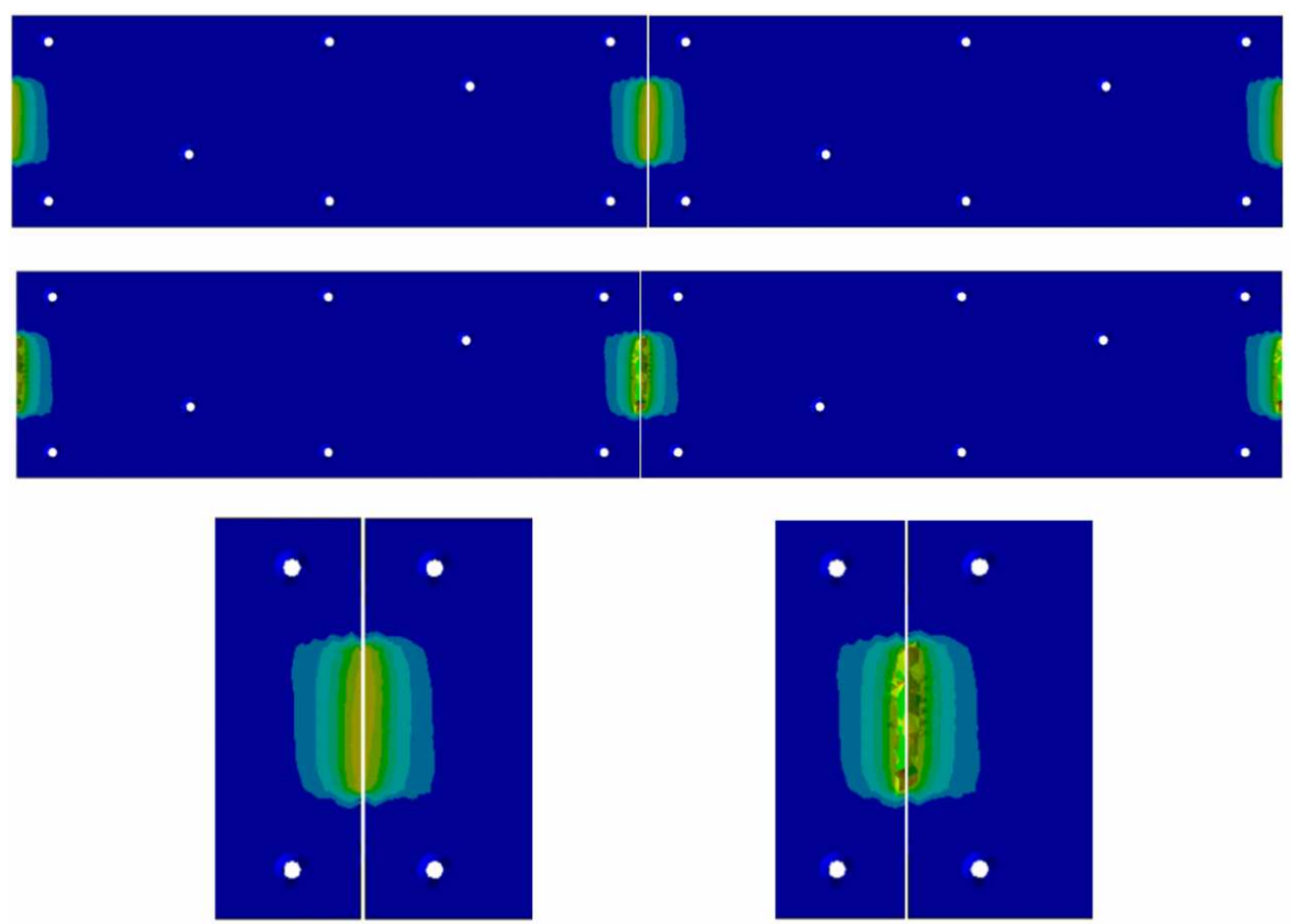

Fig. 17: Symmetrical Wear Scar developing on a perfectly aligned two panel model $225 \times 154 \mathrm{~mm}(144 \times 150 \mathrm{DPI})$ 


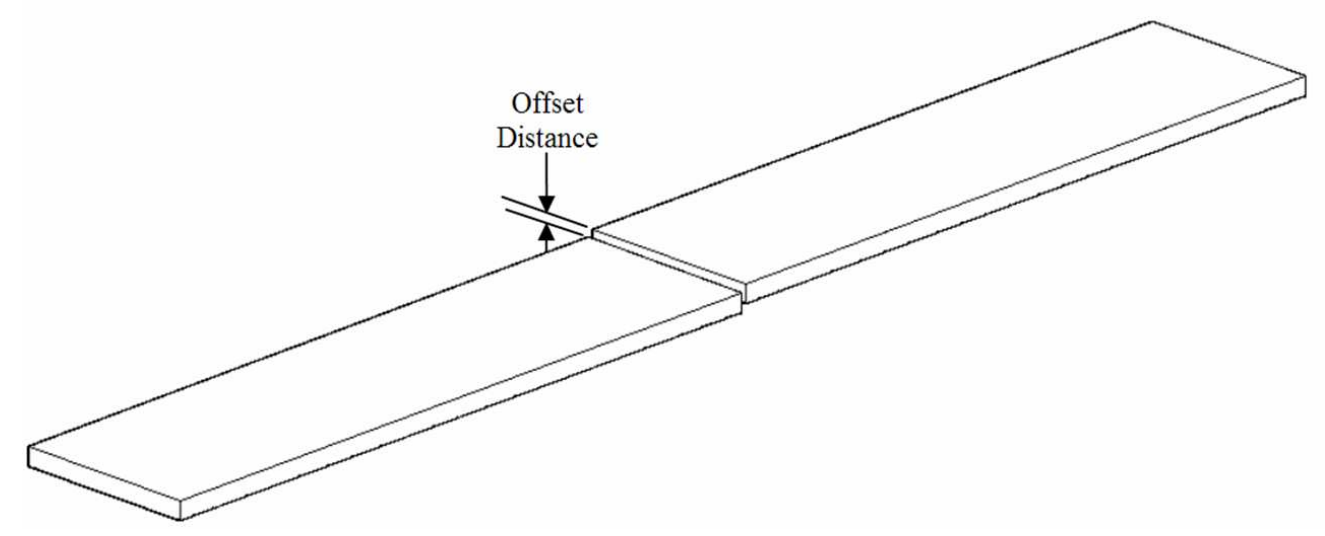

Fig. 18: Parallel Panel Misalignment Model $230 \times 88 \mathrm{~mm}$ (141 x $150 \mathrm{DPI})$ 
Fig. 19: Angled Panel Misalignment Model $239 \times 84 \mathrm{~mm}(136 \times 150 \mathrm{DPI})$ 


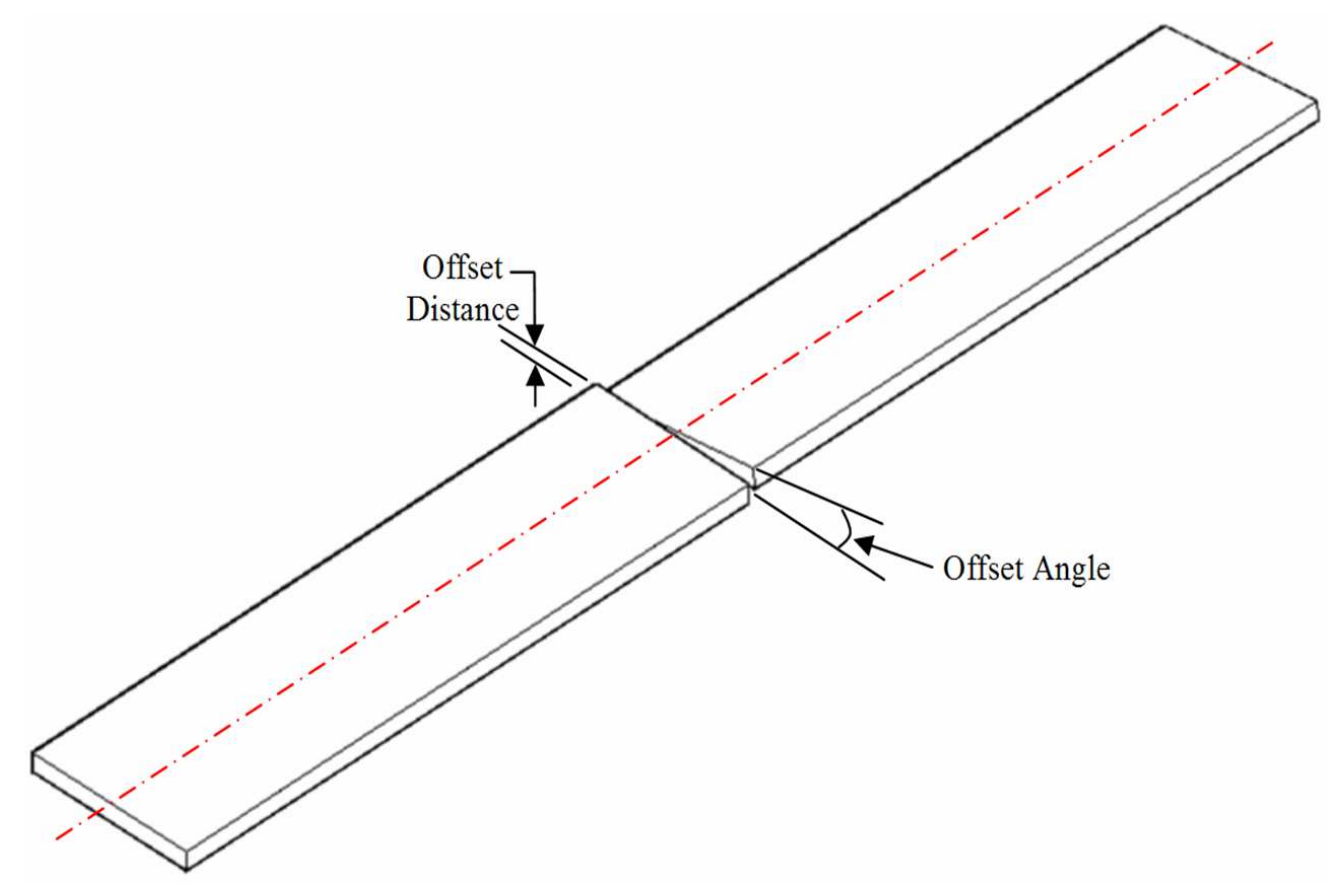

Fig. 20: Skewed Panel Misalignment Model $245 \times 145 \mathrm{~mm}(133 \times 150 \mathrm{DPI})$ 

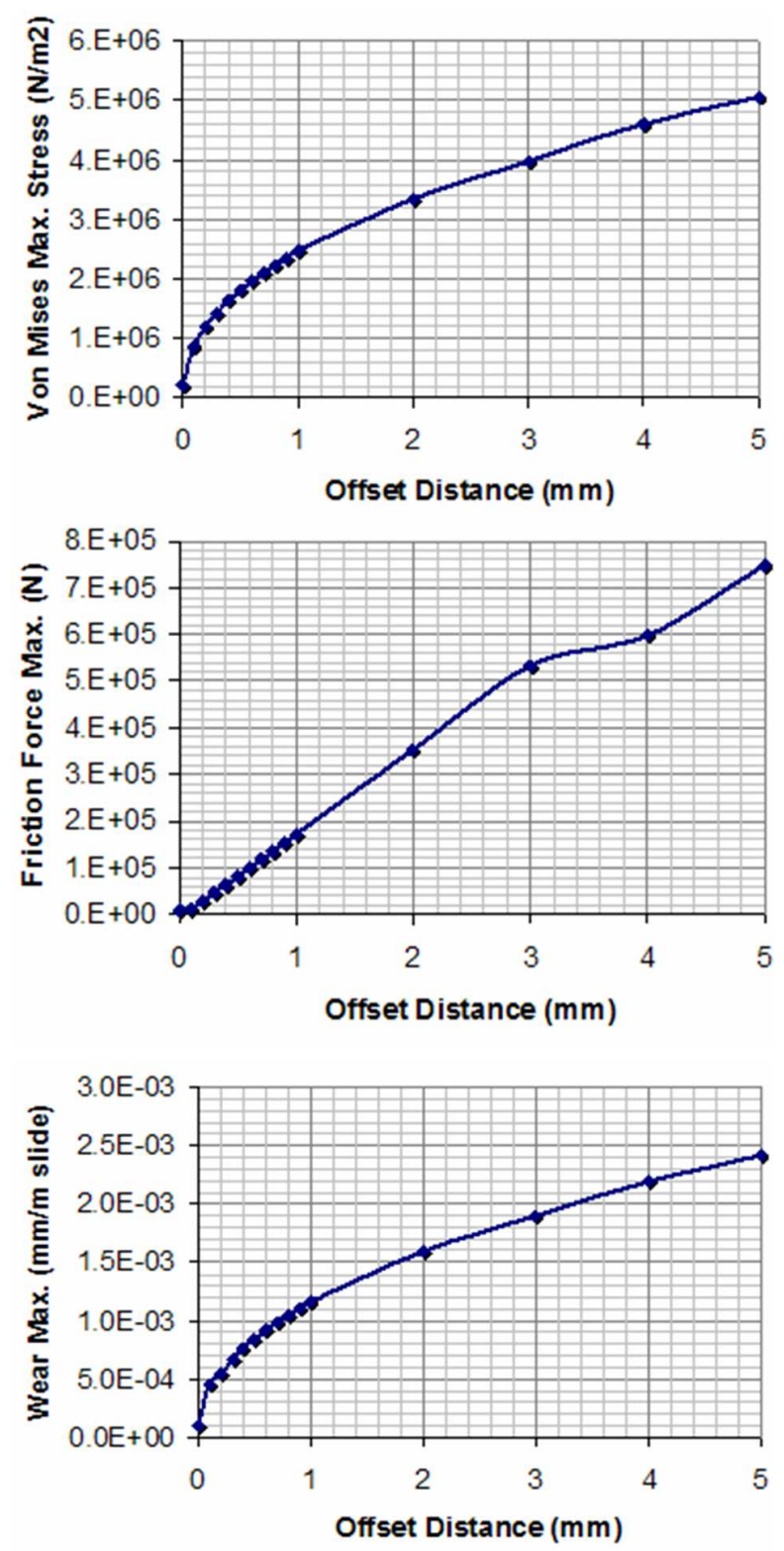

Fig. 21: Parallel Panel Offset Comparison $161 \times 325 \mathrm{~mm}(150 \times 150 \mathrm{DPI})$ 
Table 1: Equivalent number of lifeboat launches/recoveries required to generate a $19 \mathrm{~mm}$ wear scar on a $4 \mathrm{~mm}$ parallel offset misaligned slipway panel by lubricant used $114 \times 51 \mathrm{~mm}(72 \times 72 \mathrm{DPI})$ 


\begin{tabular}{|c|c|c|}
\hline $\begin{array}{l}\text { Offset dist. } \\
\text { (mm) }\end{array}$ & $\begin{array}{c}\text { Friction } \\
\text { Force Max. }\end{array}$ & $\begin{array}{c}\text { Friction Coefficient } \\
\text { Contribution }\end{array}$ \\
\hline 0 & $9.590 \mathrm{E}+03$ & 0.028 \\
\hline 0.1 & $1.195 \mathrm{E}+04$ & 0.035 \\
\hline 0.2 & $2.804 \mathrm{E}+04$ & 0.082 \\
\hline 0.3 & $4.536 \mathrm{E}+04$ & 0.133 \\
\hline 0.4 & $6.300 \mathrm{E}+04$ & 0.184 \\
\hline 0.5 & $8.096 \mathrm{E}+04$ & 0.237 \\
\hline 0.6 & $9.887 \mathrm{E}+04$ & 0.290 \\
\hline 0.7 & $1.172 \mathrm{E}+05$ & 0.343 \\
\hline 0.8 & $1.352 \mathrm{E}+05$ & 0.396 \\
\hline 0.9 & $1.534 \mathrm{E}+05$ & 0.449 \\
\hline 1 & $1.717 \mathrm{E}+05$ & 0.503 \\
\hline 2 & $3.534 \mathrm{E}+05$ & 1.035 \\
\hline 3 & $5.344 \mathrm{E}+05$ & 1.565 \\
\hline 4 & $5.984 \mathrm{E}+05$ & 1.752 \\
\hline 5 & $7.492 \mathrm{E}+05$ & 2.194 \\
\hline
\end{tabular}

Parallel Offset

\begin{tabular}{|c|c|c|}
\hline $\begin{array}{c}\text { Offset dist. } \\
(\mathrm{mm})\end{array}$ & $\begin{array}{c}\text { Friction } \\
\text { Force Max. }\end{array}$ & $\begin{array}{c}\text { Friction Coefficient } \\
\text { Contribution }\end{array}$ \\
\hline 0 & $9.590 \mathrm{E}+03$ & 0.028 \\
\hline 1 & $8.428 \mathrm{E}+04$ & 0.247 \\
\hline 2 & $1.681 \mathrm{E}+05$ & 0.492 \\
\hline 3 & $2.534 \mathrm{E}+05$ & 0.742 \\
\hline 4 & $3.360 \mathrm{E}+05$ & 0.984 \\
\hline 5 & $4.150 \mathrm{E}+05$ & 1.215 \\
\hline
\end{tabular}

Angled Offset

\begin{tabular}{|c|c|c|}
\hline $\begin{array}{c}\text { Offset dist. } \\
(\mathrm{mm})\end{array}$ & $\begin{array}{c}\text { Friction } \\
\text { Force Max. }\end{array}$ & $\begin{array}{c}\text { Friction Coefficient } \\
\text { Contribution }\end{array}$ \\
\hline 0 & $9.590 \mathrm{E}+03$ & 0.028 \\
\hline 1 & $5.587 \mathrm{E}+04$ & 0.164 \\
\hline 2 & $1.256 \mathrm{E}+05$ & 0.368 \\
\hline 3 & $1.989 \mathrm{E}+05$ & 0.582 \\
\hline 4 & $2.825 \mathrm{E}+05$ & 0.827 \\
\hline 5 & $3.560 \mathrm{E}+05$ & 1.042 \\
\hline
\end{tabular}

Skewed Offset

Table 2: Apparent friction coefficient contributions for modelled offset scenarios $315 \times 637 \mathrm{~mm}(72 \times 72$ DPI $)$ 